\title{
KEBIJAKAN HUKUM PIDANA SEBAGAI UPAYA PENANGGULANGAN KEDARURATAN COVID-19
}

\author{
(Criminal Law Policy as an Effort to Mitigate Covid-19 Emergency)
}

\author{
Aras Firdaus \\ Fakultas Hukum Universitas Quality, Universitas Sumatera Utara \\ Jl. Ngumban Surbakti No. 18 Sempakata Medan Selayang Sumatera Utara, 20132 \\ e-mail: recht_raz@yahoo.com \\ Rudy Hendra Pakpahan \\ Direktorat Jenderal Peraturan Perundang-undangan Kementerian Hukum dan Hak Asasi Manusia \\ Republik Indonesia, Universitas Sumatera Utara \\ JI. H.R. Rasuna Said Kav 6-7 Kuningan Jakarta Selatan, 12940 \\ e-mail: alvale_pph@yahoo.com
}

\begin{abstract}
Abstrak
Corona Virus Disease 2019 (Covid-19) berpotensi menimbulkan kedaruratan kesehatan masyarakat. Peraturan hukum perihal Covid-19 disahkan oleh pemerintah agar masyarakat berpartisipasi mencegah penyebaran Covid-19. Masyarakat tidak taat terhadap peraturan hukum terkait upaya penanggulangan Covid-19 dapat diupayakan melalui pendekatan hukum pidana sebagai efek jera. Hal tersebut dilakukan agar memutus rantai penyebaran Covid-19. Permasalahannya, yakni bagaimana kebijakan hukum pidana sebagai sarana untuk optimalisasi penanggulangan kedaruratan Covid-19. Metode penelitian menggunakan normatif dengan pendekatan perundang-undangan (statute approach) dilakukan dengan menelaah semua undang-undang dan regulasi yang bersangkut paut dengan isu hukum yang sedang ditangani. Pendekatan perundangundangan adalah pendekatan dengan menggunakan legislasi dan regulasi. Hasil penelitian menunjukkan langkah optimalisasi kebijakan hukum pidana sebagai upaya penanggulangan wabah pandemic Covid-19 perlu peran masyarakat dalam menaati peraturan hukum tersebut. Sehingga penyebaran Covid-19 dapat terhenti. Kesimpulan penelitian ialah optimalisasi kebijakan hukum pidana penanggulangan Covid-19 dapat dicapai jika menggabungkan beberapa strategi seperti peningkatan kebijakan hukum, budaya hukum, dan penegakan hukum yang tegas, konsisten dan terpadu. Saran peneliti ialah optimalisasi kebijakan hukum melalui peraturan hukum perihal wabah pandemi Covid-19 dapat berjalan jika pemerintah menghasilkan kebijakan yang memberikan keadilan hukum, kepastian hukum, dan kemanfaatan hukum bagi masyarakat. Kesadaran hukum masyarakat diperlukan agar berjalannya kebijakan hukum dan terhentinya wabah pandemic Covid-19.
\end{abstract}

Kata kunci: Kebijakan Hukum, Pidana, Covid-19

\begin{abstract}
The Covid 19 pandemic outbreak became a national emergency. The rule of law regarding Covid 19 was passed by the government so that the community participated in preventing the spread of Covid 19. People who do not obey the legal regulations related to the efforts of handling the pvidemic Covid 19 can be pursued through a criminal law approach as a deterrent effect. This is done in order to break the chain of distribution of Covid 19. The problem is how criminal law policy as a means of optimizing Covid's emergency response 19. The research method uses empirical normative with a statutory approach (statute approach) carried out by examining all laws and regulations related to the legal issue being handled. The statutory approach is an approach using legislation and regulations. The results of the study show that the optimization of criminal law policies as an effort to overcome the Covid 19 pandemic outbreak requires the
\end{abstract}


role of the community in obeying the rule of law. So that the spread of the Covid 19 pandemic outbreak can be stopped. The conclusion of the research is the optimization of the criminal law policy in handling Covid 19 can be achieved if it combines several strategies such as improving legal policy, legal culture, and strict, consistent and integrated law enforcement. The researcher's suggestion is to optimize legal policies through legal regulations regarding the Covid 19 pandemic outbreak if the government produces policies that provide legal justice, legal certainty, and legal benefits for the community. Public legal awareness is needed to bring legal policy to a halt in the Covid 19 epidemic.

Keywords : Legal Policy, Criminal, Covid 19

\section{A. Pendahuluan}

Corona Virus Disease 2019 (Covid-19) adalah penyakit menular yang disebabkan oleh coronavirus yang baru ditemukan. Sebagian besar orang yang terinfeksi virus Covid-19 akan mengalami penyakit pernapasan ringan hingga sedang dan sembuh tanpa memerlukan perawatan khusus. Orang yang lebih tua, dan mereka yang memiliki masalah medis mendasar seperti penyakit kardiovaskular, diabetes, penyakit pernapasan kronis, dan kanker lebih mungkin mengalami permasalahan yang serius. ${ }^{1}$

Epidemi (Covid-19) muncul di Wuhan, Cina, menyebar ke seluruh negeri dan kemudian ke negara lain antara Desember 2019 dan awal 2020. Penerapan langkah-langkah karantina ketat sebelumnya di Tiongkok telah membuat sejumlah besar orang dalam isolasi dan mempengaruhi banyak aspek kehidupan masyarakat yang memicu berbagai masalah psikologis, seperti gangguan panik, kecemasan dan depresi².

Pada 30 Januari 2020, Direktur Jenderal WHO menentukan bahwa wabah penyakit Corona Virus Disease 2019 (Covid-19) merupakan Darurat Kesehatan Masyarakat Internasional. Langkah-langkah kesehatan untuk mengurangi penyebaran virus ini salah satunya dengan karantina. Karantina melibatkan pembatasan gerak baik yang sehat maupun yang sakit dengan tujuan pemantauan dan memastikan deteksi dini kasus baru. Banyak negara memiliki otoritas hukum untuk memaksakan karantina. Karantina harus diimplementasikan hanya sebagai bagian dari paket komprehensif respon kesehatan masyarakat dan tindakan penahanan dan, sesuai dengan Pasal 3 dari Peraturan Kesehatan Internasional (2005), sepenuhnya menghormati martabat, hak asasi manusia, dan kebebasan dasar seseorang Karantina termasuk dalam kerangka hukum Peraturan Kesehatan Internasional (2005), khususnya: Pasal 30 Wisatawan yang berada di bawah pengawasan kesehatan masyarakat; Pasal 31 - Tindakan kesehatan terkait dengan masuknya penjelajah; Pasal 32 - Perawatan wisatawan ${ }^{3}$.

Indonesia saat ini menjadi salah satu negara di dunia yang terpapar oleh virus Covid-19. Sejak pertama kali virus tersebut terdeteksi pada 2 Maret 2020 dan diumumkan langsung oleh Presiden Joko Widodo, angka kasus wabah virus menunjukkan bahwa paling tidak sampai saat ini, peningkatan terlihat cukup signifikan dan stabil dengan rata-rata 100 kasus per hari. Kurva angka kasus Covid-19 pun sama sekali belum menunjukkan kecenderungan menurun.

\footnotetext{
https://www.who.int/health-topics/coronavirus\#tab=tab_1(diakses pada 8 Mei 2020)

2 J.Qiu, B.shen, M.Zhao, et al, 2020, A nationwide survey of psychological distress among Chinese people in the COVID-19 epidemic: Implications and policy, Gen Psychiatr,Vol 33, No 2.

3 https://www.socialscienceinaction.org/resources/february-2020-social-science-humanitarian-action-platform/ (diakses pada 8 Mei 2020)
} 
Berbagai sumber, baik dari dalam maupun luar negeri, telah memprediksi angka kasus Covid-19 di Indonesia akan mencapai puluhan bahkan ratusan ribu. ${ }^{4}$

Pemerintah pun segera bertindak untuk menanggulangi penyebaran Covid-19, mulai dari kontak tracking (pelacakan) pada orangorang yang pernah berkontak dengan pasien positif, menyiapkan rumah sakit rujukan untuk merawat dan mengisolasi pasien, hingga menjadikan Wisma Atlet sebagai rumah sakit darurat. Pembangunan rumah sakit khusus penyakit menular di Pulau Galang pun dilakukan. Selain itu, pemerintah mengumumkan status darurat kesehatan dan menerbitkan Peraturan Pemerintah nomor 21 tahun 2020 tentang Pembatasan Sosial Berskala Besar. Gugus Tugas Percepatan Penanganan Covid-19 juga dibentuk untuk menentukan langkah-langkah strategis. ${ }^{5}$

Terkait perkembangan virus corona tersebut, akhirnya pemerintah membuat kebijakan sebagai langkah pertama yaitu berupa anjuran social distancing. Ini dimaknai bahwa pemerintah menyadari sepenuhnya penularan dari covid-19 ini bersifat droplet percikan lendir kecil-kecil dari dinding saluran pernapasan seseorang yang sakit yang keluar pada saat batuk dan bersin. Oleh karena itu, pemerintah menganjurkan kepada siapapun yang batuk dan yang menderita penyakit influenza untuk menggunakan masker. Selain mengatur jarak antar orang, agar kemungkinan peluang tertular penyakit bisa menjadi lebih rendah. Implikasinya bahwa pertemuan-pertemuan dengan jumlah yang besar dan yang memungkinkan terjadinya penumpukan orang harus dihindari. Karenanya sangat penting untuk disadari bersama dari seluruh komponen masyarakat untuk tidak melaksanakan kegiatan yang mengerahkan banyak orang dalam satu tempat yang tidak terlalu luas dan menyebabkan kerumunan. Hal ini dianggap sebagai salah satu upaya yang sangat efektif untuk mengurangi sebaran virus. Oleh karena itu, social distancing harus diimplementasikan, baik dalam kehidupan sehari-hari, di lingkungan kerja ataupun di lingkungan rumah tangga. Selain tetap melakukan pencegahan melalui upaya pola hidup bersih dan sehat dengan selalu mencuci tangan menggunakan sabun dengan air yang mengalir. ${ }^{6}$

Alat yang biasa digunakan untuk tes Covid-19 di Indonesia terdapat dua jenis yakni PCR dan Rapid Test. Kedua alat tersebut memiliki perbedaan dalam teknis penggunaannya maupun hasil yang didapatkan. PCR adalah alat untuk mendeteksi Covid-19, alat ini bekerja dengan mendeteksi kandungan genetik pada virus tersebut. Pemeriksaan menggunakan Polymerase Chain Reaction (PCR) memakai sampel lendir dari hidung atau tenggorokkan. Ketika sampel cairan dari saluran pernapasan bawah tiba di lab, para peneliti mengesktrak asam nukleat di dalamnya. Asam nukleat tersebut mengandung genom virus yang dapat menentukan adanya infeksi atau tidak dalam tubuh. Hasil tes biasanya keluar dalam waktu beberapa hari. Sedangkan, Rapid Test adalah alat untuk mendeteksi Covid-19 yang sudah dikembangkan di beberapa negara seperti di

4 Mohammad Hasan Ansori, 2020, Wabah COVID-19 dan Kelas Sosial di Indonesia, THC Insights, No. 14, Hal. 1

5 Jessica Martha, 2020, Pemanfaatan Diplomasi Publik oleh Indonesia dalam Krisis Covid-19, Jurnal IImiah Hubungan Internasional, Edisi Khusus, Hal. 3

6 Nur Rohim Yunus dan Annissa Rezki, 2020, Kebijakan Pemberlakuan Lockdown Sebagai Antisipasi Penyebaran Corona Virus Covid-19, Jurnal Sosial \& Budaya Syar-I, Vol. 7, No. 3, Hal. 203. 
Singapura dan Cina. Rapid test terbilang hanya membutuhkan waktu yang singkat untuk penggunaanya. Kurang lebih 15 hingga 20 menit hasil tes akan keluar. Rapid test adalah metode skrining awal untuk mendeteksi antibodi, yaitu IgM dan IgG, yang diproduksi oleh tubuh untuk melawan virus Corona. Antibodi ini akan dibentuk oleh tubuh bila ada paparan virus Corona. Akan tetapi tes menggunakan rapid test memiliki kekurangan yakni bisa menghasilkan diagnosis negatif. Namun bisa saja diagnosis negatif sebenarnya positif terinfeksi. Biasanya diagnosis negatif meski sebenarnya positif, terjadi saat tes dilakukan kurang dari 7 hari setelah terinfeksi virus corona Covid-19. Lebih jauh lagi, pada saat awal kasus Covid-19 muncul, Indonesia masih belum siap dengan fasilitas penunjangnya di rumah sakit. Hal ini ditunjukkan dengan alat PCR yang baru dipesan oleh BUMN dari Swiss bekerja sama dengan perusahaan Roche Holding AG dan rencananya alat tersebut baru akan disebar ke beberapa provinsi?

Menurut analisis International Monetary Fund (IMF), ekonomi global bakal susut setidaknya 3\% tahun ini diakibatkan oleh pandemi Covid-19. Sedangkan di Indonesia, Menteri Keuangan Sri Mulyani memprediksi ekonomi Indonesia minus 0,4\% tahun ini. Sejak kasus pertama Covid-19 diumumkan awal Maret 2020 lalu, data Kementerian Ketenagakerjaan mendapati bahwa sudah ada 1,5 juta lebih buruk lagi adalah tingkat kesadaran masyarakat yang masih rendah pada aturan PSBB. Menurut penelusuran peneliti CSIS Noory Oktariza untuk The Jakarta Post, pergerakan keluar-masuk
Jakarta sejak 3 April 2020 tetap tinggi. Tak sedikit yang bergerak dalam radius ratusan kilometer dari ibu kota, memperkuat dugaan bahwa jutaan penduduk ibu kota mudik duluan karena khawatir terhadap pandemi atau kehilangan pekerjaan. ${ }^{8}$

Kerugian yang paling mudah dihitung adalah kerugian agregat secara nasional. Namun karena bersifat makro, maka perhitungan ini hanya digunakan oleh pelaku ekonomi skala besar, atau oleh negara dalam menyusun (revisi) APBN. Salah satu cara menghitung dapat menggunakan acuan Produk Domestik Bruto (PDB), yang merupakan akumulasi total produksi di sebuah negara selama setahun. PDB per kapita Indonesia per tahun pada 2019 menurut Badan Pusat Statistik (BPS) adalah USD 4.174,9 atau Rp 59,1 juta (kurs Rp 14.156-per USD). Dengan jumlah penduduk 267 juta jiwa, maka PDB Indonesia pada 2019 adalah sebesar Rp15.833,9 Triliun. Pertumbuhan ekonomi Indonesia pada 2020 semula diperkirakan sebesar 5,3\%, namun angka ini terkoreksi sebagai dampak pandemi Corona, dan sebagian kalangan memprediksikan pertumbuhan di bawah 2\%, serta terjadi fluktuasi kurs USD (peningkatan drastis menjadi Rp 16.000 per USD pada awal April 2020) pertumbuhan ekonomi Januari-April 2020 dan kurs USD pada masa krisis. Sehingga angka PDB yang digunakan pada tulisan ini adalah acuan 2019. ${ }^{9}$

Jumlah korban yang berjatuhan baik dari masyarakat biasa maupun para tenaga kesehatanakibat virus SARS COV-2 atau yang dikenal dengan Covid-19. Cicero,

Adelia Rachma Indriaswari Susanto, 2020, Kajian Politik Hukum Pemerintah dalam Penanganan Pandemi Covid-19, Sebuah Kajian, Hal. 13.

8 Sylvia Hasanah Thorik, 2020, Efektivitas Pembatasan Sosial Berskala Besar Di Indonesia Dalam Penanggulangan Pandemi Covid-19, 'Adalah: Buletin Hukum Dan Keadilan, Vol. 4, No. 1, Hal. 118.

9 Wibowo Hadiwardoyo, 2020, Kerugian Ekonomi Nasional Akibat Pandemi Covid-19, Baskara: Journal Of Business And Entrepreneurship, Vol. 2, No. 2, Hal. 84-85. 
mengatakan, "Salus populi suprema lex esto", keselamatan rakyat merupakan hukum tertinggi bagi suatu Negara.Pemerintah tidak tinggal diam,dari data yang dikeluarkan oleh Kementrian Keuangan,dana Rp. 405,1 Triliun (Kementrian Keuangan, 2020) dikeluarkan untuk menangagulangi pandemik ini, tentu dana yang luar biasa dalam penangganan Covid-19. Covid-19 merupakan singkatan dari Corona (CO), Virus (VI), Disease (D, penyakit) yang ditemukan pada Tahun 2019. Presiden mengeluarkan Peraturan Pemerintah Penganti Undang-undang Nomor 1 Tahun 2020 untuk mempercepat penanganan Covid-19 dan menstabilkan perekonomian Negara. Namun Pasal 27 menimbulkan perdebatan dikalangan ahli hukum tentang apakah ada kekebalan didalam pasal tersebut. ${ }^{10}$

Kebijakan Hukum Terhadap Penanganan Pandemi Covid-19 Di Indonesia belum dapat dilaksanakan dengan baik sebagaimana yang diamanatkan dalam peraturan perundangundangan, karena masih banyak masyarakat yang melanggar dalam kegiatan PSBB. Walapun sudah sangat jelas ada sanksi pidana yang dapat dikenakan bagi yang melakukan pelanggaran. Dengan keadaan yang demikian seharusnya Pemerintah Pusat dan Pemerintah Daerah memastikan keterbukaan informasi publik secara nyata untuk dapat mengetahui rantai penyebaran virus tersebut, dan harus dapat menjamin dan memastikan terutama kepada kaum menengah ke bawah mampu memenuhi kebutuhannya untuk menjamin hak atas hidup masyarakatnya dan tidak terkurangi suatu apapun harkat martabat masyarakatnya (sesuai amanat UUD NRI Tahun 1945) dan perlunya peran publik dalam hal saling menjaga, saling mengingatkan, dan saling membantu satu sama lain. ${ }^{11}$

Kebijakan hukum diatas sebenarnya dapat terjadi pada suatu Negara hukum. Kebijakan yang diambil lebih didasarkan pada Legal Policy yang bertujuan untuk kemaslahatan warga masyarakat. Upaya menyelamatkan warga masyarakat dari wabah pandemi Covid-19. Suatu kebijakan dalam menetapkan suatu perbuatan yang semula bukan tindak pidana menjadi suatu perbuatan yang dapat dipidana. Jadi hakikatnya kebijakan kriminalisasi merupakan bagian dari kebijakan kriminal (criminal policy) dengan menggunakan sarana hukum pidana (penal) sehingga termasuk bagian dari kebijakan hukum pidana (penal policy). Permasalahannya ialah bagaimana kebijakan hukum pidana sebagai sarana untuk optimalisasi penanggulangan kedaruratan Covid-19?

\section{B. Metode Penelitian}

Tipe Penelitian ialah penelitian hukum normatif, yaitu penelitian hukum yang objek utamanya adalah noma-norma atau kaidahkaidah dari aturan-aturan hukum positif yang mengatur kebijakan hukum pidana sebagai upaya penanggulangan kedaruratan Covid-19, terutama yang bertujuan untuk terwujudnya kebijakan hukum yang memberikan keadilan hukum, kepastian hukum, dan kemanfaatan hukum. Penelitian ini bersifat deskriptif yaitu menggambarkan keadaan dari aturan-aturan hukum yang mengatur hubungan antara kebijakan hukum pidana dan masyarakat terkait upaya penanggulangan kedaruratan Covid-19.

\footnotetext{
Volume 9 Nomor 1

11 Putu Sekarwangi Saraswati, 2020, Kebijakan Hukum Terhadap Penanganan Pandemi Covid-19 di Indonesia, Kertha Wicaksana: Sarana Komunikasi Dosen Dan Mahasiswa Volume 14, Nomor 2, Hal. 151.
} 


\section{Sumber Data}

Penelitian hukum normatif atau doktrinal merupakan penelitian hukum yang meletakkan hukum sebagai sebuah bangunan sistem norma. ${ }^{12}$ Penelitian hukum normatif dapat dilakukan dengan menganalisis aturan hukum dan kemudian konstruksi dilakukan dengan memasukkan artikel ke dalam kategori berdasarkan pengertian sistem hukum. Kesimpulan untuk menjawab masalah dilakukan oleh menggunakan logika berpikir deduktif. Metode deduktif dilakukan dengan membaca, menafsirkan, dan membandingkan hubungan konsep, prinsip, dan aturan terkait sehingga memperoleh kesimpulan sesuai dengan tujuan penulisan yang dirumuskan ${ }^{13}$.

Pada penelitian hukum normatif empiris dikonsepsikan sebagai apa yang tertulis dalam peraturan perundang-undangan (law in books). ${ }^{14}$ Sumber data penelitian normatif yaitu Data primer, peraturan-peraturan hukum yang melandasi institusi atau lembaga dan berbagai literatur yang membahas Covid-19.

Data sekunder, informasi tentang implementasi dari peraturan-peraturan hukum yang melandasi institusi atau lembaga, struktur dan mekanime kebijakan hukum pidana sebagai upaya penanggulangan kedaruratan Covid-19. Terutama dari hasil-hasil penelitian yang lalu, dan tulisan-tulisan para pakar hukum dari berbagai literatur, media massa, dokumendokumen, dan sumber informasi lainnya.

Data tersier, yaitu semua dokumen yang berisi tentang konsep-konsep dan keterangan keterangan yang mendukung bahan hukum primer dan bahan hukum sekunder, seperti kamus, ensklopedia dan sebagainya. Teknik pengumpulan data dilakukan dengan cara studi kepustakaan (library reseacrh) dan juga dengan melakukan wawancara langsung dengan informan (field reseacrh). Hasil dari kegiatan pengkajian tersebut kemudian dibuat ringkasan secara sistematis sebagai inti sari hasil pengkajian studi dokumen. Pengolahan, analisis dan konstruksi data penelitian hukum normatif dapat dilakukan dengan cara melakukan analisis terhadap kaidah hukum dan kemudian konstruksi dilakukan dengan cara memasukkan pasal-pasal ke dalam kategorikategori atas dasar pengertian-pengertian dari sistem hukum tersebut. Penarikan kesimpulan untuk menjawab permasalahan dilakukan dengan menggunakan logika berfikir deduktif. Metode deduktif dilakukan dengan membaca, menafsirkan dan membandingkan hubunganhubungan konsep, asas dan kaidah yang terkait sehingga memperoleh kesimpulan yang sesuai dengan tujuan penulisan yang dirumuskan. Sementara itu, untuk penelitian empiris, data primer berupa informasi-informasi yang diperoleh dari hasil wawancara dengan para infoman (mereka yang dianggap paling tahu perihal objek yang diteliti).

\section{Teknik Pengumpulan}

Data Teknik pengumpulan data dilakukan dengan library research atau kepustakaan dengan tujuan inventarisasi data-data primer (peraturan-peraturan perundang-undangan dan

12 Mukti Fajar dan Yulianto Achmad, Dualisme Penelitian Hukum Normatif \& Empiris, Cet. III, (Yogyakarta: Pustaka Pelajar, 2015), hlm. 34.

13 Aras Firdaus, 2018, Legal Protection of Children as a Victim Exploitation, International Conference Of Asean Perspective And Policy, Vol. 1, No.1, Hal. 272.

14 Amiruddin dan Zainal Asikin, Pengantar Metode Penelitian Hukum, Cet. IX, (Jakarta: PT. Raja Grafindo Persada, 2016), hlm. 118. 
aturan hukum) juga data sekunder (literatur dan hasil penelitian terdahulu), juga berbagai kamus, serta wawancara dengan informan, yaitu pakar yang dianggap kompeten di bidangnya.

\section{Pendekatan Penelitian}

Pendekatan yang digunakan adalah pendekatan perundang-undangan (statute approach). Pendekatan undang-undang (statute approach) dilakukan dengan menelaah semua undang-undang dan regulasi yang bersangkut paut dengan isu hukum yang sedang ditangani. Pendekatan perundang-undangan adalah pendekatan dengan menggunakan legislasi dan regulasi.

\section{Pembahasan}

\section{Kebijakan Hukum Pidana sebagai Sarana Optimalisasi Penanggulangan Kedaruratan Covid-19}

Kitab Undang-undang Hukum Pidana yang dikenal dengan KUHP merupakan suatu aturan kodifikasi dalam hukum pidana yang seharusnya memuatsemuaaturantindakpidanadidalamnya, akan tetapi hal itu tidak mungkin karena seiring dengan perkembangan jaman akan timbul perbuatan-perbuatan (tindak pidana) baru yang belum diatur dalam KUHP. Maka diciptakanlah oleh penguasa berbagai peraturan perundangundangan yang di dalamnya memuat tindak pidana baru yang belum diatur dalam KUHP. Dalam perkembangan hukum pidana dewasa ini di Indonesia, terutama dalam Undang-undang Pidana Khusus atau Perundang-undangan pidana di luar Kitab Undang-undang Hukum Pidana (KUHP), terdapat suatu kecenderungan menerapkan sistem dua jalur dalam stelsel sanksinya. Dalam KUHP sendiri juga menerapkan sistem dua jalur dalam stelsel sanksinya, hal ini tercantum dalam pasal 10 KUHP yang memuat sanksi Pidana yang terdiri dari pidana pokok dan pidana tambahan dan Pasal 44 KUHP yang memuat sanksi tindakan berupa perawatan dirumah sakit jiwa bagi orang yang tidak mampu bertanggungjawab atas tindak pidana yang dilakukan karena terganggu jiwanya. Dalam hal penerapan sistem dua jalur dalam stelsel sanksinya, Indonesia menganut sistem dua jalur dalam pemidanaan (double track system), yaitu di samping pembuat tindak pidana dapat dijatuhi pidana, dapat juga dikenakan berbagai tindakan. Dalam Konsep KUHP pengenaan sanksi tindakan bukan hanya untuk orang yang tidak mampu bertanggungjawab karena gangguan jiwa, melainkan orang yang mampu bertanggungjawab juga dapat dikenakan sanksi tindakan. Penerapan "sistem dua jalur" dalam peraturan perundang-undangan di Indonesia dikarenakan penerapan sanksi pidana saja selama ini dianggap belum efektif dalam menanggulangi tindak pidana yang terjadi di Indonesia. ${ }^{15}$

World Health Organization (WHO) menjelaskan bahwa Corona virus (Cov) adalah virus yang menginfeksi sistem pernapasan. Infeksi virus ini disebut Covid-19. Virus Corona menyebabkan penyakit flu biasa sampai penyakit yang lebih parah seperti Sindrom Pernafasan Timur Tengah (MERS-CoV) dan Sindrom Pernafasan Akut Parah (SARS-CoV). Virus Corona adalah zoonotic yang artinya ditularkan antara hewan dan manusia. Berdasarkan Kementerian Kesehatan Indonesia, perkembangan kasus Covid-19 di Wuhan berawal pada tanggal 30 Desember 2019 dimana Wuhan Municipal Health Committee mengeluarkan pernyataan

15 Dwi Wiharyangti, 2011, Implementasi Sanksi Pidana dan Sanksi Tindakan dalam Kebijakan Hukum Pidana di Indonesia, Pandecta, Vol. 6, No. 1, Hal. 80. 
"urgent notice on the treatment of pneumonia of unknown cause". Penyebaran virus Corona ini sangat cepat bahkan sampai ke lintas negara. Sampai saat ini terdapat 188 negara yang mengkorfirmasi terkena virus Corona. Penyebaran virus Corona yang telah meluas ke berbagai belahan dunia membawa dampak pada perekonomian Indonsia, baik dari sisi perdagangan, investasi dan pariwisata. ${ }^{16}$

Sebagian besar negara tidak siap dengan kecepatan dan skala dampak dari Covid-19. Beberapa peraturan nasional telah dibuat oleh pemerintah pada tingkat presiden sampai tingkat menteri selama Januari-Maret 2020. Kepala Badan Nasional Penanggulangan Bencana (BNPB) ditunjuk sebagai komandan. Sebelum Keputusan ini, respons tingkat nasional minimal seperti yang ditunjukkan oleh hanya dua peraturan sektoral yang dikeluarkan. Pertama adalah deklarasi Kementerian Kesehatan Novel 2019-nCov sebagai penyakit yang menguraikan potensi transformasi Covid-19 menjadi wabah dan apa yang dapat dilakukan. Kedua, deklarasi nasional tentang situasi darurat khusus Covid-19 oleh kepala BNPB. Salah satu yang paling penting adalah Instruksi Presiden 4 Tahun 2020. Instruksi Presiden memiliki poin utama yang menyerukan strategi cepat dan aktif terkait dengan merealokasi anggaran, memastikan ketahanan pangan, memperkuat sektor kesehatan melalui layanan kesehatan dasar dan skema asuransi nasional (BPJS) untuk pasien Covid-19, mengubah metode pengajaran dan pembatalan ujian nasional, memperkuat pemerintah daerah dan ekonomi lokal, pengurangan pajak untuk komoditas terpilih, implementasi berbagai strategi ekonomi dan fiskal untuk memastikan mereka yang terkena dampak menerima kompensasi tertentu. Beberapa arahan kebijakan ini telah ditindaklanjuti di tingkat menteri. Baik pemerintah pusat dan daerah bekerja sama dengan para pemangku kepentingan terkait untuk melaksanakan arahan Presiden. Namun tidak jelas apakah kita dapat mengatakan bahwa rekomendasi telah dilaksanakan. Namun, Instruksi tersebut (Inpres 4 Tahun 2020) tidak cukup kuat untuk menciptakan imperatif skala nasional untuk dengan cepat mengakhiri penyebaran Covid-19. Oleh karena itu, tekanan telah dibuat oleh banyak pemangku kepentingan. Dan akhirnya, Presiden Indonesia mengeluarkan satu dekrit dan dua peraturan mendasar pada hari terakhir bulan Maret 2020. Peraturan-peraturan ini meliputi: Pertama, Peraturan tentang penganggaran nasional kebijakan dan stabilitas sistem penganggaran untuk bencana pandemi Covid-19, mengelola ancaman bagi ekonomi nasional dan stabilisasi sistem penganggaran; Kedua, Pernyataan situasi darurat kesehatan masyarakat untuk Covid-19; Ketiga, pembatasan sosial skala besar untuk mempercepat pemberantasan Covid-19 (Instruksi Presiden Nomor 4 Tahun 2020) secara khusus menginstruksikan untuk memfokuskan kembali kegiatan pembangunan, realokasi anggaran pemerintah, dan pengadaan barang dan jasa untuk respon cepat dan terakselerasi terhadap Covid-19 (Refocussing Kegiatan, Realokasi Anggaran, Serta Pengadaan Barang dan Jasa di tempat Percepatan Penanganan Penyakit Corona Virus 2019) ${ }^{17} 18$.

Mobilitas manusia merupakan salah satu faktor yang turut mempercepat penyebaran

Silpa Hanoatubun, 2020, Dampak Covid - 19 Terhadap Perekonomian Indonesia, EduPsyCouns Journal, Vol. 2, No. 1, Hal. 3. 
virus Covid-19. Di Cina, sampai dengan 23 Januari 2020 - sebelum Wuhan menetapkan status lockdown - sebagian besar laporan mengenai kasus-kasus awal Covid-19 berasal dari Provinsi Hubei (81\% dari keseluruhan kasus saat itu), sementara mayoritas dari kasus yang dilaporkan terjadi di luar Kota Wuhan umumnya memiliki sejarah perjalanan dari kota tersebut. Adanya waktu yang dibutuhkan untuk gejala dapat muncul dan teridentifikasi sebagai orang terinfeksi Covid-19 memberikan kesempatan untuk virus tersebut dapat bertransmisi dari satu orang ke banyak orang lainnya di lokasilokasi berbeda. Akibatnya, virus ini pun menyebar dengan cepat ke berbagai negara lainnya. Kebijakan-kebijakan yang dimaksud meliputi pembatasan masuknya orang-orang dari negara-negara terdampak Covid-19, penangguhan penerbangan, pembatasan visa, penutupan perbatasan, hingga karantina. Penerapan berbagai kebijakan tersebut tentu saja dapat mengganggu lalu lintas mobilitas manusia di tingkat regional maupun internasional. Sementara itu, di level domestik sendiri, pemerintah di berbagai negara juga mulai menerapkan kebijakan lockdown yang juga berfokus untuk membatasi ruang gerak masyarakat yang ada. Pertanyaan penting yang kemudian muncul adalah kebijakan pembatasan mobilitas seperti apakah yang dikeluarkan dan dampak apa yang telah dan mungkin muncul akibat dari pembatasan tersebut. ${ }^{19}$

Situasi karantina yang menjadi dampak atas menyebarnya COVID-19 menyebabkan ikatan sosial pada masyarakat dunia menjadi renggang. Kebijakan lockdown menggunakan prinsip distancing nyatanya tidak hanya membuat masyarakat menjauh secara fisik, tetapi juga sosial. Masyarakat tanpa sadar telah terjebak ke dalam jarak fisik maupun sosial yang sangat signifikan. Ke depannya, jarak sosial dan fisik yang melebar ini dipercaya akan menjadi sesuatu yang normal. Kondisi manusia ketika wabah COVID-19 ini selesai akan semakin menegaskan fungsi teknologi dalam menjadi perantara interaksi manusia. Interaksi manusia secara langsung selanjutnya akan digantikan oleh interaksi tidak langsung. Hal ini berpadu dengan hadirnya tantangantantangan peradaban yang baru, mulai dari ancaman pengawasan pemerintah via teknologi, meningkatnya kontrol pemerintah atas privasi publik, hingga fenomena hilangnya solidaritas global dalam menghadapi ancaman darurat. ${ }^{20}$

\section{Penegakan Hukum terhadap Pelanggaran Penanggulangan Kedaruratan Covid-19}

Tantangan dinamika peristiwa hukum yang terjadi khususnya di Indonesia, merupakan tantangan negara dalam kedudukannya sebagai Negara hukum. Penerapan maupun penegakan hukum, merupakan elemen-elemen sistem hukum yang secara terus menerus untuk disikapi, guna mewujudkan kedudukan hukum dinegara hukum dan bermanfaat bagi kepentingan masyarakat, bangsa dan negara. ${ }^{21}$ Soerjono Soekanto bahwa agar hukum itu berfungsi dimasyarakat diperlukan adanya keserasian antara empat faktor, yakni pertama,

https://covid19.go.id/ (diakses pada 9 mei 2019).

18 Djalante a Riyanti, et. Al .2020. Review and analysis of current responses to COVID-19 in Indonesia: Period of January to March 2020, Progress in Disaster Science.Vol 6.1-9.

19 Sylvia Yazid dan Liliana Dea Jovita, 2020, Dampak Pandemi Terhadap Mobilitas Manusia di Asia Tenggara, Jurnal IImiah Hubungan Internasional, Edisi Khusus, Hal. 76.

20 Putu Agung Nara Indra Prima Satya, 2020, COVID- 19 dan Potensi Konflik Sosial, Jurnal IImiah Hubungan Internasional, Edisi Khusus, Hal. 3-4. 
adanya sinkronisasi yang sistematis diantara kaidah-kaidah hukum atau peraturan baik secara vertikal maupun horizontal sehingga tidak bertentangan satu sama lain; kedua, pelaksana penegak hukum mempunyai pedoman yang jelas tentang kewenangannya dalam menjalankan tugas, sekaligus kualitas kepribadian petugas untuk melaksanakan dan mentaati peraturan yang diberlakukan; ketiga, derajat kepatuhan hukum masyarakat terhadap hukum sangat mempengaruhi pelaksanaan hukum. Derajat kepatuhan hukum ini tergantung dari proses pembuatan hukum. Keempat, fasilitas atau sarana pendukung pelaksanaan hukum harus memadai secara fisik. ${ }^{22}$ Secara konsepsional, maka penegakan hukum terletak pada kegiatan menyerasikan hubungan nilainilai yang terjabarkan di dalam kaidah-kaidah yang mantap dan mengejawantah dan sikap tindak sebagai rangkaian penjabaran nilai tahap akhir, untuk menciptakan, memelihara, dan mempertahankan kedamaian pergaulan hidup. Konsepsi yang mempunyai dasar filosofis tersebut, memerlukan penjelasan lebih lanjut, sehingga akan tampak lebih konkret.

Undang-Undang Nomor 6 Tahun 2018 tentang Kekarantinaan Kesehatan, khususnya pasal 93 memang sudah mengatur tentang aturan bagi pelanggar pembatasan sosial berskala besar (PSBB) memberikan ancaman sanksi pidana paling lama 1 (satu) tahun dan/atau pidana denda paling banyak Rp.100.000.000,00 (seratus juta rupiah) Selain Pasal 218 KUHP dinyatakan adanya ancaman pidana penjara paling lama empat bulan dua minggu atau pidana denda paling banyak sembilan ribu rupiah bagi siapa saja pada waktu rakyat datang berkerumun dengan sengaja tidak segera pergi setelah diperintah tiga kali oleh atau atas nama penguasa yang berwenang. Hal ini kemudian ditindaklanjuti pemerintah dengan mengeluarkan Peraturan Pemerintah (PP) Nomor 21 Tahun 2020 tentang Pembatasan Sosial Berskala Besar (PSBB). Karenanya, saat Peraturan Pemerintah telah resmi dikeluarkan, maka pihak kepolisian sebagaimana amanat Presiden secara tegas melakukan tindakan upaya penegakan hukum bagi pelanggarnya. Artinya, pencegahan wabah pandemi Covid-19 ini harus dilakukan dengan memberikan sanksi pidana bagi masyarakat yang melakukan pelanggaran. Melalui Maklumat Kapolri Nomor Mak/2/III/2020 tentang Kepatuhan Terhadap Kebijakan Pemerintah dalam Penanganan Penyebaran Virus Corona, kemudian pihak kepolisian melakukan tindakan mengamankan masyarakat yang tidak menaati aturan mengenai PSBB tersebut. ${ }^{23}$

Pelanggar kebijakan Pembatasan Sosial Berskala Besar (PSBB) melalui Peraturan Walikota Pekanbaru Nomor 74 Tahun 2020 tentang Pedoman Pelaksanaan PSBB dalam Penanganan Covid-19 mulai disidang dan diberi sanksi pidana Dalam sidang itu ada 15 orang yang didakwa melanggar PSBB. Mereka dijatuhi hukuman penjara selama dua bulan dan denda Rp 800 ribu hingga Rp 3 juta oleh Majelis Hakim Pengadilan Negeri Pekanbaru Ini merupakan perkara pertama PSBB di Indonesia naik ke meja hijau. Vonis terhadap pelanggar PSBB ini pun dilakukan secara virtual oleh jaksa dan majelis hakim di Pengadilan Negeri Pekanbaru. Sedangkan ke-15 terdakwa berada di aula Polresta Pekanbaru. Vonis diberikan karena

21 Faisal Santiago, 2017, Penegakan Hukum Tindak Pidana Korupsi oleh Penegak Hukum untuk Terciptanya Ketertiban Hukum, Pagaruyung Law Journal, Vol. 1, No. 1, Hal. 34-35.

22 Soerjono Soekanto, Sosiologi Hukum Dalam Masyarakat, (Jakarta: Rajawali, 1979). 
para terdakwa terbukti secara sah melanggar Pasal 216 KUHP karena tidak menuruti perintah atau permintaan pejabat berwenang sesuai UU tugasnya mengawasi sesuatu. ${ }^{24}$

Dalam rangka penegakan hukum, ada 3 (tiga) hal yang perlu mendapat perhatian. Pertama, substansi hukum, yaitu peraturan perundangundangan harus dijalan sebagaimana seharusnya. Kedua, struktur hukum, yaitu perlunya penguatan secara yuridis berbagai aspek di bidang kelembagaan hukum agar dapat melaksanakan perintah undang-undang. Ketiga, budaya hukum yang meliputi sikap baik aparatur penegak hukum maupun masyarakat. Dengan demikian, maka bidang penegakan hukum merupakan masalah yang strategis menentukan peranan fungsi hukum dalam menciptakan kepastian hukum untuk mencapai keadilan. tentunya bila ketegasan ini ditegakkan akan banyak warga masyarakat yang melanggar menjadi tahanan, yang kemudian secara hukum harus diadili dan dipenjarakan.

\section{Hambatan Implementasi Kebijakan Hukum Pidana Perihal Penangulangan Kedaruratan Covid-19}

Tiga perubahan paling umum dalam perilaku publik adalah bertahan rumah, mencuci tangan lebih banyak, dan menerapkan jarak sosial. Sementara beberapa massyarakat lebih memperhatikan risiko daripada yang lain, respons masyarakat harus dilihat sebagai kunci untuk mengakhiri pandemi ini. Mereka harus dilihat sebagai bagian dari solusi dan bukan masalah. Pada fase awal wabah, tampak jelas bahwa skeptisisme dan keragu-raguan Pemerintah, atau bahkan penolakan terhadap potensi pandemi yang terjadi di Indonesia, memiliki dampak langsung dan membuat masyarakat menjauh dari persepsi risiko yang menguntungkan untuk menangkal pandemi tersebut. Ini ditambah dengan kesadaran dan latihan yang relatif rendah tentang pandemi, meskipun sejumlah sosialisasi telah difasilitasi misalnya oleh Departemen Kesehatan di masa lalu. Persepsi orang tentang risiko Covid-19 mungkin rendah meskipun arus informasi yang kompleks dan cepat sejak Januari 2020. Diperlukan waktu bagi masyarakat umum untuk memproses informasi tentang Covid-19 dan mengambil tindakan serius untuk melindungi diri. Belakangan, istilah-istilah teknis yang disederhanakan terkait dengan Covid-19 diperkenalkan ke dalam bahasa lokal seperti yang diprakarsai oleh beberapa akademisi dan pakar. Terminologi bahasa Inggris seperti "Social Distancing" telah secara harfiah diadopsi oleh pemerintah dan masyarakat umum.

Pada umumnya orang berpendapat bahwa kesadaran warga masyarakat terhadap hukum yang tinggi mengakibatkan para warga masyarakat mematuhi ketentuan peraturan perundang - undangan yang berlaku. Sebaliknya apabila kesadaran warga masyarakat terhadap hukum rendah, maka derajat kepatuhannya juga rendah. Pernyataan yang demikian berkaitan dengan fungsi hukum dalam masyarakat. Peningkatan kesadaran seyogianya dilakukan melalui penerangan dan penyuluhan hukum yang teratur atas dasar perencanaan yang mantap. Penyuluhan hukum bertujuan agar warga masyarakat mengetahui dan memahami hukumhukum tertentu. Penerangan dan penyuluhan hukum harus disesuaikan dengan masalahmasalah hukum yang ada dalam masyarakat

23 Nur Rohim Yunus, 2020, Kebijakan Covid-19, Bebaskan Narapidana dan Pidanakan Pelanggar PSBB, 'Adalah: Buletin Hukum Dan Keadilan, Vol. 4, No. 1, Hal. 5

24 https://kumparan.com/selasarriau/pertama-di-indonesia-pelanggar-psbb-divonis-kurungan-penjara 
pada suatu waktu yang menjadi sasaran penyuluhan hukum. kesadaran hukum atau yang mencakup kesadaran hukum adalah konsepsi mengenai kebudayaan hukum (legal culture). Konsepsi ini secara relatif baru dikembangkan, dan salah satu kegunaannya adalah untuk dapat mengetahui perihal nilai-nilai terhadap prosedur hukum maupun substansinya. Apabila ajaranajaran tentang kesadaran hukum dibandingkan dengan konsepsi kebudayaan hukum, konsepsi kebudayaan hukum lebih luas ruang lingkupnya. Hal ini disebabkan hukum terdapat di dalam setiap masyarakat manusia, betapa pun sederhana dan kecilnya masyarakat tersebut. ${ }^{25}$

Covid-19 merupakan penyakit virus yang berbahaya bagi manusia. Saat menghadapi wabah penyakit yang sudah mendunia ini, terutama yang berawal dari negara Cina, pemerintah Cina melakukan kebijakan suatu aturan agar masyarakat tidak boleh ada yang keluar, namun semakin virus itu menyebar sehingga berdampak pada negaranegara lainnya termasuk Indonesia. Kejadian penyebaran virus corona ini membuat semua masyarakat resah dan tidak tahu apa yang harus dilakukan saat kejadian seperti ini. Masyarakat masih mampu untuk melaksanakan bela negara walaupun dalam keadaan virus corona atau Covid-19. Dengan kejadian seperti ini haruslah ada kesepakatan bersama bukan mengkritik bersama untuk mencapai tujuan bersama yaitu melawan Covid-19.

Dari kebijakan tersebut masyarakat mampu mentaati aturan yang dibuat karena kebijakan tersebut baik untuk kemaslahatan warga negara, dari banyak kasus tentang virus corona ini membuat kekhawatiran bagi pemerintah maupun warga negara karena angka kematian penduduk yang cukup tinggi. Oleh karena itu pemerintah sudah menghimbau masyarakat agar berdiam rumah untuk pencegahan Covid-19.

Kesadaran kolektif masyarakat di era industri modern dan terutama dalam konteks informasi teknologi saat ini dinilai "lemah". Berkurangnya fungsi keluarga, fungsi kerabat, fungsi tatap muka dan relasi dengan tetangga digantikan oleh berbagai aturan di tengah dunia yang marak penggunaan media daring menyebabkan banyak individu tidak lekat dengan kolektivitas di sekitarnya. Situasi ini ditambah dengan situasi politik yang terjadi di Indonesia beberapa tahun terakhir yang menciptakan disintegrasi dan polarisasi sosial. Dalam situasi ketidaklekatan kolektifitas, pandemi Covid-19 memberikan "struktur baru" yang membuat manusia harus bekerja kolektif untuk memastikan perubahan perilaku secara kolektif sebagai satu-satunya cara memutus mata rantai penyebaran virus ini. Mudahnya penularan virus Covid-19 dan efek kemungkinan mematikan bagi mereka yang terpapar menyebabkan virus ini yang mengendalikan kecepatan penambahan pasien baru yang bergerak secara eksponensial. Berbagai lembaga kesehatan telah menyimpulkan bahwa penurunan penyebaran virus Covid-19 sangat tergantung pada perubahan perilaku seluruh manusia untuk mencuci tangan, memakai masker saat berinteraksi, melakukan karantina sendiri, dan menjaga jarak fisik. Jika perubahan perilaku tidak terjadi secara kolektif, konsekuensinya tidak hanya berdampak bagi kematian dan trauma mereka yang ditinggalkan, tapi juga terhadap berbagai kehidupan ekonomi,

\footnotetext{
Atang Hermawan Usman, 2014, Kesadaran Hukum Masyarakat Dan Pemerintah Sebagai Faktor Tegaknya Negara Hukum Di Indonesia, Wawasan Yuridika, Vol. 30, No.1, Hal. 47.
} 
sosial dan kesehatan mental masyarakat. ${ }^{26}$

Semakin meluasnya wabah dan dampak dari virus ini secara signifikan didalam segisegi kehidupan masyarakat Indonesia, maka menjaga kesehatan mental tetap dalam kondisi prima adalah suatu keharusan. Mental yang sehat akan membuat kepuasaan hidup yang erat kaitannya dengan kebahagiaan dimana orang yang bahagia akan memiliki sistem imun yang tinggi, sehingga dapat menangkal wabah virus tersebut. Bila dikaitkan dengan pandemi Covid-19 ini, maka ada baiknya manusia berpikir dan memaknai sisi positif dari hadirnya wabah tersebut. Bisa dihayati bahwa dengan adanya pandemi ini seluruh manusia dapat bersatu padu dan saling menumbuhkan rasa saling peduli satu dengan yang lainnya sehingga tumbuhnya cinta kasih yang mungkin dalam waktu belakangan ini manusia mengedepankan kebencian dan konflik. Polusi berkurang dari bumi, sehingga bumi memiliki waktu untuk dapat memperbaiki dirinya, sehingga dapat menjadi tempat yang lebih baik untuk ditinggali. Ataupun setiap manusia akan menjadi lebih sadar akan esensi dari kehidupan, sehingga setelahnya dapat berperilaku dengan lebih baik. Dari hal-hal tersebut, maka manusia akan berada dalam kondisi tenang dan awas adalam menghadapi wabah ini. Selain itu manusia juga akan lebih siap dan kuat dalam menghadapi peristiwa traumatis lainnya di masa depan. ${ }^{27}$

Dampak jika tidak Implementasi dengan baik Kebijakan Hukum Perihal Penangulangan Kedaruratan Covid-19 yaitu:

\section{a. Dampak Kesehatan}

Melalui beberapa model statistic tentang pandemi Covid-19, ditemukan sebuah penjelasan tentang seberapa lama virus ini akan bertahan hingga menimbulkan dampak dan berangsur-angsur menurun virulensinya. Kemampuan virus ini dari menyebabkan infeksi hingga individu mengalami kesembuhan secara global adalah berkisar 30-40 hari. Hal tersebut jika dilihat dari kurva yang dihitung di Wuhan, China dari rentang akhir Februari hingga awal April. Estimasi kurva tersebut bukan merupakan estimasi individual namun merupakan estimasi global pada suatu wilayah. Kurva tersebut dapat sesuai dengan perkiraan namun dapat juga terjadi perlambatan (memanjang) dikarenakan perbedaan regulasi yang diterapkan masingmasing pemerintah. Kurva tersebut diperoleh saat pemerintah di China melakukan karantina wilayah yang sangat ketat, larangan kunjungan wisatawan dari negara lain, tertutupnya akses darat dan udara serta pelarangankeluar dari rumah selain membeli makanan dan obatobatan. ${ }^{28}$

Interval serial Covid-19 mendekati atau lebih pendek dari median masa inkubasinya. Ini menunjukkan bahwa sebagian besar penularan sekunder dapat terjadi sebelum timbulnya penyakit. Interval serial Covid-19 juga lebih pendek dari interval serial sindrom pernafasan akut yang parah (SARS), menunjukkan bahwa perhitungan yang dibuat dengan menggunakan interval serial SARS dapat menimbulkan bias ${ }^{29}$.

Melihat fakta di atas, kemungkinan besar Indonesia akan mengalami perlambatan puncak pandemi. Dengan kata lain, Indonesia akan mengalami perpanjangan pandemi dikarenakan tidak adanya penetapan terhadap karantina wilayah yang sangat ketat. Hal ini menimbulkan

Yulia Indri Sari, 2020, Sisi Terang Pandemi COVID-19, Jurnal Ilmiah Hubungan Internasional, Edisi Khusus, Hal. 2.

27 Dana Riksa Buana, 2020, Analisis Perilaku Masyarakat Indonesia dalam Menghadapi Pandemi Virus Corona (Covid-19) dan Kiat Menjaga Kesejahteraan Jiwa, SALAM; Jurnal Sosial \& Budaya Syar-I, Vol. 7, No. 3, Hal. 222-223. 
kemungkinan tertularnya individu terutama dari Red Zone (zona merah) menuju ke Green Zone (zona hijau). Lambat laun, seluruh Indonesia akan menjadi Zona Merah. Ditambah lagi dengan ketidakpatuhan beberapa masyarakat yang tetap keluar rumah, tidak menggunakan masker, tetap mengadakan perkumpulan, yang justru menambah semakin tingginya orang yang terinfeksi Covid-19. Pandemi di Indonesia bisa jadi akan bertahan hingga 4-6 bulan ke depan. Yusufa Ibnu Sina Setiawan, 2020, Penetapan Karantina Wilayah Menurut Pandangan Legal Positivisme Dalam Rangka Pencegahan dan Pemberantasan Pandemi Corona Virus Disease (Covid)-19.

\section{b. Dampak Ekonomi}

Ditahun 2020, perekonomian global tidak bisa diukur dengan hanya sebatas lingkup ekonomi itu sendiri. Virus Corona (Covid-19) menjadi bukti bahwa virus yang mengganggu kesehatan tersebut dapat menimbulkan ketidakstabilan ekonomi pada suatu negara bahkan dalam skala global. Indonesia sendiri termasuk negara yang dipastikan akan terkena dampak dari virus corona. Direktur Pelaksana Bank Dunia Mari Elka Pangestu memperkirakan pertumbuhan ekonomi Indonesia bisa melemah di bawah 5\% pada kuartal I-2020. Mari mengatakan penurunan PDB Cina hingga satu persen poin akan mengkoreksi pertumbuhan ekonomi Indonesia sebesar 0,3 persen poin. Pelemahan ekonomi Indonesia bisa terjadi karena Cina merupakan salah satu mitra dagang terbesar Indonesia. Cina juga merupakan salah satu penyumbang wisatawan terbesar Indonesia. Di depan anggota parlemen Indonesia pada 28 Januari 2020 Menteri
Keuangan Sri Mulyani sudah mengingatkan dampak virus Corona terhadap perekonomian Indonesia. Menurut Sri Mulyani, munculnya virus corona telah memunculkan pesimisme terhadap pertumbuhan ekonomi dunia. Melihat peran China yang begitu besar berdasarkan data BPS, impor nonmigas Indonesia dari Cina tercatat mencapai 44,578 miliar dolar AS pada 2019--terbesar dibandingkan impor dari negaranegara lain. Sementara ekspor Indonesia ke Cina tercatat sebesar 25,852 miliar dolar AS. ${ }^{30}$

Beberapa dampak ekonomi yang terjadi di negara lain adalah banyak sector-sektor baik perdagangan, informal maupun pariwisata yang merugi. Siklus perputaran uang kacau, dikarenakan banyaknya kerugian yang dialami pengusaha. Namun tidak dapat dipungkiri bahwa beberapa komoditi menjadi untung terutama mereka yang menyediakan alat-alat kesehatan ataupun segala sesuatu yang terkait dengan pemberantasan atau pencegahan Covid-19 ini. ${ }^{31}$

Di tengah penyebaran virus Covid-19, rantai pasokan mengalami gangguan yang sangat signifikan karena adanya pengurangan kapasitas untuk memproses, penutupan jalan dan pelabuhan, serta pembatasan transportasi, yang memperlambat produksi pertanian dan distribusi pangan dari produsen ke konsumen. Gangguan ini telah menyebabkan kenaikan harga pangan di Indonesia. Harga rata-rata beras di wilayah Indonesia selama minggu pertama bulan April adalah Rp11.900,- per kilogram, ada kenaikan sebesar 1,28\% dari harga pada bulan Desember 2019. Di provinsi-provinsi yang memberlakukan Pembatasan Sosial Berskala Besar (PSBB) seperti DKI Jakarta, harga beras bahkan lebih tinggi, hingga Rp13.500,- per

2 Petropoulos, F., Makridakis, S. 2020. Forecasting The Novel Coronavirus COVID-19. Journal PlosOne, March 312020.

29 Nishiura, H., Linton, N. M., \& Akhmetzhanov, A. R. (2020). Serial interval of novel coronavirus (COVID-19) infections. International journal of infectious diseases. 
kilogram di pasar-pasar tradisional, karena masyarakat menimbun bahan makanan. Kenaikan harga untuk komoditas pangan yang perlu diimpor bahkan lebih signifikan. Dari Desember hingga pertengahan April 2020, harga gula meningkat hingga $32,97 \%$ menjadi Rp18.350,- per kilogram, bawang putih meningkat sebanyak 35,64\% menjadi Rp43.200,- per kilogram, sementara harga daging sapi tetap tinggi di angka Rp117.750,- per kilogram ${ }^{32}$.

Masalah ekonomi lainnya yang dihadapi Indonesia ialah kinerja dan kapasitas debitur dalam menjalankan kewajiban kreditnya telah terganggu oleh penyebaran Covid-19, yang berpotensi mengganggu kinerja perbankan dalam manajemen kredit. Mendorong optimalisasi fungsi perantara perbankan diperlukan suatu kebijakan dalam menanggulangi dampak penyebaran Covid-19. Pengaturan kebijakan dalam mengatasi ketidakstabilan ekonomi akibat penyebaran Covid-19 adalah penerbitan kebijakan untuk memberikan stimulus ekonomi nasional melalui penerapan Peraturan Otoritas Jasa Keuangan No.11/POJK.03/2020. Kebijakan ini mengatur adanya restrukturisasi kredit, yaitu kualitas kredit yang direstrukturisasi dapat ditentukan dengan lancar jika diberikan kepada debitur yang teridentifikasi dipengaruhi oleh penyebaran Covid-19. Implementasi skema restrukturisasi dapat bervariasi dan ditentukan oleh kebijakan masing-masing bank tergantung pada penilaian profil debitur dan kapasitas untuk membayar. Kami menekankan bahwa di tengah ketidakpastian, seperti kebijakan saat ini akan sangat berguna jika masing-masing pihak mengambil proses dengan hati-hati dan bertanggung jawab ${ }^{33}$.

Pemerintah tidak akan bisa meminimalkan kematian dari penyakit coronavirus 2019 (Covid-19) dan dampak ekonomi dari penyebaran virus. Meminimalisir kematian serendah mungkin akan menjadi prioritas tertinggi bagi individu, karenanya pemerintah harus menerapkan langkah-langkah untuk memperbaiki krisis ekonomi yang tak terhindarkan ${ }^{34}$.

\section{Penutup}

Kebijakan-kebijakan yang dimaksud meliputi pembatasan masuknya orang-orang dari negara-negara terdampak Covid-19, penangguhan penerbangan, pembatasan visa, penutupan perbatasan, hingga karantina. Situasi karantina yang menjadi dampak atas menyebarnya COVID-19 menyebabkan ikatan sosial pada masyarakat dunia menjadi renggang. Suatu kebijakan dalam menetapkan suatu perbuatan yang semula bukan tindak pidana (tidak dipidana) menjadi suatu tindak pidana (perbuatan yang dapat dipidana). Tantangan dinamika peristiwa hukum yang terjadi khususnya di Indonesia, merupakan tantangan negara dalam kedudukannya sebagai Negara hukum. Konsepsi yang mempunyai dasar filosofis tersebut, memerlukan penjelasan lebih lanjut, sehingga akan tampak lebih konkret. Undang-Undang Nomor 6 Tahun 2018 tentang

30 Chairul Iksan Burhanuddin Dan Muhammad Nur Abdi, 2020, Ancaman Krisis Ekonomi Global Dari Dampak Penyebaran Virus Corona (Covid-19), Akmen Jurnal IImiah, Volume 17 Nomor 1, Hal. 717.

31 Binti Hamzah FA, Lau C, Nazri H, Ligot DV, Lee G, Tan CL, et al. CoronaTracker: World- wide COVID-19 Outbreak Data Analysis and Prediction. [Submitted]. Bull World Health Organ. E-pub: 19 March 2020. doi: http://dx.doi.org/10.2471/ BLT.20.255695.

32 Amanta, Felippa, and Ira Aprilianti.2020. "Indonesian Food Trade Policy during Covid-19." Center for Indonesian Policy Studies.

33 Hari Sutra Disemadi, Ali Ismail Shaleh,2020, Banking credit restructuring policy amid COVID-19 pandemic in Indonesia,Jurnal Inovasi Ekonomi,Vol 5, No 2. 
Kekarantinaan Kesehatan, khususnya Pasal 93 memang sudah mengatur tentang aturan bagi pelanggar pembatasan sosial berskala besar (PSBB) memberikan ancaman sanksi pidana paling lama 1 (satu) tahun dan/atau pidana denda paling banyak Rp100.000.000,00 selain Pasal 218 KUHP dinyatakan adanya ancaman pidana penjara paling lama empat bulan dua minggu atau pidana denda paling banyak sembilan ribu rupiah bagi siapa saja pada waktu rakyat datang berkerumun dengan sengaja tidak segera pergi setelah diperintah tiga kali oleh atau atas nama penguasa yang berwenang. Hal ini kemudian ditindaklanjuti pemerintah dengan mengeluarkan Peraturan Pemerintah (PP) Nomor 21 Tahun 2020 tentang Pembatasan Sosial Berskala Besar (PSBB). Mereka dijatuhi hukuman penjara selama dua bulan dan denda Rp 800 ribu hingga Rp 3 juta oleh Majelis Hakim Pengadilan Negeri Pekanbaru Ini merupakan perkara pertama PSBB di Indonesia naik ke meja hijau. Vonis terhadap pelanggar PSBB ini pun dilakukan secara virtual oleh jaksa dan majelis hakim di Pengadilan Negeri Pekanbaru. Dalam rangka penegakan hukum, ada 3 (tiga) hal yang perlu mendapat perhatian. Kedua, struktur hukum, yaitu perlunya penguatan secara yuridis berbagai aspek di bidang kelembagaan hukum agar dapat melaksanakan perintah undang-undang. tentunya bila ketegasan ini ditegakkan akan banyak warga masyarakat yang melanggar menjadi tahanan, yang kemudian secara hukum harus diadili dan dipenjarakan. Tiga perubahan paling umum dalam perilaku publik adalah bertahan rumah, mencuci tangan lebih banyak, dan menerapkan jarak sosial. Sementara beberapa masyarakat lebih memperhatikan risiko daripada yang lain, respons masyarakat harus dilihat sebagai kunci untuk mengakhiri pandemi ini. Penerangan dan penyuluhan hukum harus disesuaikan dengan masalah-masalah hukum yang ada dalam masyarakat pada suatu waktu yang menjadi sasaran penyuluhan hukum. Apabila ajaranajaran tentang kesadaran hukum dibandingkan dengan konsepsi kebudayaan hukum, konsepsi kebudayaan hukum lebih luas ruang lingkupnya.

Pandemi COVID-19 telah memunculkan peran penting masyarakat sipil dalam rangka mendukung pemerintah merespon bencana nasional dan global ini. Kepemimpinan nasional dan negara yang kuat memang dibutuhkan untuk memutus mata rantai penularan virus COVID-19 dan mengatasi dampak dari kebijakan karantina wilayah dan pembatasan sosial di berbagai aspek kehidupan masyarakat terutama di aspek ekonomi dan sosial. Tetapi hal tersebut perlu disertai dengan inisiatif dan tindakan masyarakat untuk saling mendukung, mengingatkan akan pentingnya bertindak dan mengubah perilaku sebagai bagian dari kesadaran kolektif. Menyadari bahwa individu adalah bagian dari masyarakat yang lebih luas.

Colson, P., Rolain, J. M., Lagier, J. C., Brouqui, P., \& Raoult, D. (2020). Chloroquine and hydroxychloroquine as available weapons to fight COVID-19. Int J Antimicrob Agents, 105932(10.1016). 


\section{Daftar Pustaka}

\section{A. Buku}

Amiruddin dan Asikin, Zainal, Pengantar Metode Penelitian Hukum, Cet. IX, (Jakarta: PT. Raja Grafindo Persada, 2016).

Fajar, Mukti dan Achmad, Yulianto, Dualisme Penelitian Hukum Normatif \& Empiris, Cet. III, (Yogyakarta: Pustaka Pelajar, 2015).

Soekanto, Soerjono, Sosiologi Hukum Dalam Masyarakat, (Jakarta: Rajawali, 1979).

\section{B. Jurnal}

Amanta, Felippa, and Ira Aprilianti.. "Indonesian Food Trade Policy during Covid-19." Center for Indonesian Policy Studies (2020).

Ansori, Mohammad Hasan, 'Wabah Covid-19 dan Kelas Sosial di Indonesia", THC Insights, No. 14. (2020).

Binti Hamzah FA, Lau C, Nazri H, Ligot DV, Lee G, Tan CL, et al. "CoronaTracker: World- wide Covid-19 Outbreak Data Analysis and Prediction". [Submitted]. Bull World Health Organ. (2020)

Buana, Dana Riksa, "Analisis Perilaku Masyarakat Indonesia dalam Menghadapi Pandemi Virus Corona (Covid-19) dan Kiat Menjaga Kesejahteraan Jiwa", SALAM; Jurnal Sosial \& Budaya Syar-I, Vol. 7, No. 3. (2020).

Burhanuddin, Chairul Iksan dan Abdi Muhammad Nur, "Ancaman Krisis Ekonomi Global Dari Dampak Penyebaran Virus Corona (Covid-19)", Akmen Jurnal Ilmiah, Volume 17 Nomor 1. (2020).

Colson, P., Rolain, J. M., Lagier, J. C., Brouqui, P., \& Raoult, D. "Chloroquine and hydroxychloroquine as available weapons to fight Covid-19". Int J Antimicrob Agents, 105932(10.1016), (2020).

Djalante a Riyanti, et. Al. "Review and analysis of current responses to Covid-19 in Indonesia: Period of January to March 2020", Progress in Disaster Science.Vol 6.1-9. (2020).

Disemadi, Hari Sutra dan Shaleh, Ali Ismail, "Banking credit restructuring policy amid Covid-19 pandemic in Indonesia", Jurnal Inovasi Ekonomi, Vol 5, No 2. (2020).

Firdaus, Aras, "Legal Protection of Children as a Victim Exploitation", International Conference Of Asean Perspective And Policy, Vol. 1, No.1, (2018).

Hadiwardoyo, Wibowo, Kerugian Ekonomi Nasional Akibat Pandemi Covid-19, Baskara: Journal Of Business And Entrepreneurship, Vol. 2, No. 2. (2020).

Hanoatubun, Silpa, Dampak Covid - 19 Terhadap Perekonomian Indonesia, EduPsyCouns Journal, Vol. 2, No. 1, (2020).

J.Qiu, B.shen, M.Zhao, et al, "A nationwide survey of psychological distress among Chinese people in the COVID-19 epidemic: Implications and policy", Gen Psychiatr,Vol. 33, No. 2. (2020).

Martha, Jessica, "Pemanfaatan Diplomasi Publik oleh Indonesia dalam Krisis Covid-19", Jurnal IImiah Hubungan Internasional, Edisi Khusus, (2020).

Nishiura, H., Linton, N. M., \& Akhmetzhanov, A. R. "Serial interval of novel coronavirus (Covid-19) infections". International journal of infectious diseases. (2020).

Nur Rohim Yunus, "Kebijakan Covid-19, Bebaskan Narapidana dan Pidanakan Pelanggar PSBB", Adalah: Buletin Hukum Dan Keadilan, Vol. 4, No. 1, (2020).

Petropoulos, F., Makridakis, S. 2020. Forecasting The Novel Coronavirus Covid-19. Journal 
PlosOne, March 312020

Saraswati, Putu Sekarwangi, Kebijakan Hukum Terhadap Penanganan Pandemi Covid-19 di Indonesia, Kertha Wicaksana: Sarana Komunikasi Dosen Dan Mahasiswa Volume 14, Nomor 2, (2020).

Sari, Yulia Indri, Sisi Terang Pandemi Covid-19, Jurnal IImiah Hubungan Internasional, Edisi Khusus. (2020).

Satya, Putu Agung Nara Indra Prima, , Covid- 19 dan Potensi Konflik Sosial, Jurnal Ilmiah Hubungan Internasional, Edisi Khusus, (2020).

Susanto, Adelia Rachma Indriaswari, "Kajian Politik Hukum Pemerintah dalam Penanganan Pandemi Covid-19", Sebuah Kajian (2020).

Thorik, Sylvia Hasanah, Efektivitas Pembatasan Sosial Berskala Besar Di Indonesia Dalam Penanggulangan Pandemi Covid-19, 'Adalah: Buletin Hukum Dan Keadilan, Vol. 4, No. 1, (2020).

Ubwarin, Erwin dan Corputty, Patrick, "Pertangungjawaban Pidana Dalam Keadaandarurat bencana covid-19", Mizan: Jurnal Ilmu Hukum, Volume 9 Nomor 1. (2020). Usman, Atang Hermawan, "Kesadaran Hukum Masyarakat Dan Pemerintah Sebagai Faktor Tegaknya Negara Hukum Di Indonesia", Wawasan Yuridika, Vol. 30, No. 1, (2014).

Wiharyangti, Dwi, "Implementasi Sanksi Pidana dan Sanksi Tindakan dalam Kebijakan Hukum Pidana di Indonesia", Pandecta, Vol. 6, No. 1, (2011).

Yazid, Sylvia dan Jovita, Liliana Dea, Dampak Pandemi Terhadap Mobilitas Manusia di Asia Tenggara, Jurnal Ilmiah Hubungan Internasional, Edisi Khusus, (2020).

Yunus, Nur Rohim dan Rezki, Annissa, "Kebijakan Pemberlakuan Lockdown Sebagai Antisipasi Penyebaran Corona Virus Covid-19", Jurnal Sosial \& Budaya Syar-I, Vol. 7, (2020).

\section{Peraturan Perundang-undangan}

Kitab Undang-undang Hukum Pidana

Undang-Undang Nomor 6 Tahun 2018 tentang Kekarantinaan Kesehatan

Peraturan Pemerintah Nomor 21 tahun 2020 tentang Pembatasan Sosial Berskala Besar Maklumat Kapolri No. Mak/2/III/2020 Tentang Kepatuhan Terhadap Kebijakan Pemerintah Dalam Penanganan Penyebaran Virus Corona (Covid-19)

Peraturan Otoritas Jasa Keuangan tentang Stimulus Perekonomian Nasional Sebagai Kebijakan Countercyclical Dampak Penyebaran Corona Virus Disease 2019 No. 11 / POJK.03 / 2020.

Peraturan Walikota Pekanbaru Nomor 74 Tahun 2020 tentang Pedoman Pelaksanaan Pembatasan Sosial Berskala Besar.

\section{Internet}

https://kumparan.com/selasarriau/pertama-di-indonesia-pelanggar-psbb-divonis-kurunganpenjara

https://www.who.int/health-topics/coronavirus\#tab=tab_1(diakses pada 8 Mei 2020)

https://covid19.go.id/ (diakses pada 9 mei 2019) 


\section{BIODATA PENULIS}

Aras Firdaus, S.H., M.H, lahir di Medan. Menyelesaikan pendidikan strata satu (S1) sarjana hukum pada Fakultas Hukum Universitas Sumatera Utara (USU) tahun 2013. Melanjutkan pendidikan starta dua (S2) magister hukum Fakultas Hukum Universitas Sumatera Utara (USU) tahun 2015 dan penulis sedang menyelesaikan strata tiga (S3) studi program doktor IImu Hukum di Universitas Sumatera Utara (USU) tahun 2018 sampai sekarang. Sejak tahun 2016 hingga saat ini tercatat sebagai dosen jabatan asisten ahli di Fakultas Hukum Universitas Quality dan praktisi hukum. Selain aktif mengajar, juga aktif dalam organisasi yaitu anggota perhimpunan advokat Indonesia (PERADI) Sumatera Utara, anggota Himpunan Peneliti Indonesia (Himpenindo) wilayah Sumatera Utara periode 2019-2024, editor pengelola jurnal nomoi law review, dan editor pengelola jurnal justiqa. Penulis aktif dalam beberapa kegiatan ilmiah baik naisonal maupun internasional. Penelitian ilmiah yaitu hibah penelitian dosen pemula Kementerian Riset, Teknologi, dan Perguruan Tinggi tahun 2018 dan 2019.

Rudy Hendara Pakpahan, S,H., M.Hum, lahir di Sibolga. Pekerjaan Pegawai Negeri Sipil (PNS) di Kementerian Hukum dan Hak Asasi Manusia Republik Indonesia. Stratra satu (S1) Ilmu Hukum di selesaikan di Universitas Andalas tahun 2004, strata dua (S2) Universitas Sumatera Utara tahun 2009, dan sedang menyelesaikan studi strata tiga (S3) Ilmu Hukum Universitas Sumatera Utara tahun 2018 sampai sekarang. Publikasi ilmiah di jurnal nasional yaitu tanggung jawab negara dalam pelaksanaan jaminan sosial, pengawasan peraturan daerah dikaitkan dengan tugas dan fungsi Kantor Wilayah Kementerian Hukum dan Hak Asasi Manusia, dan analisi prosedur pengujian peraturan daerah. 